\title{
Thrombotic Inception at Nano-Scale
}

\author{
Suryyani Deb and Anjan Kumar Dasgupta \\ Department of Biochemistry, University of Calcutta \\ India
}

\section{Introduction}

Seeing is believing, but the reverse, namely, disbelieving the unseen may often go against the spirit of scientific exploration. This is particularly true for nano-scale objects interacting almost invisibly with biological cells, tissues or organs. Interestingly many of the biological sub-cellular components (e.g. proteins, DNA)have nano-scale dimension. The apparently innocent (chemically inactive) and tiny particulate matter originating from various natural or artificial sources (e.g., pollutant) have been shown to be toxic at different physiological levels. The famous saying by Jeevaka, the legendary physician of the Jataka tales, that there is no herb in the world that is not a drug, however follows. What is toxic in some context have important therapeutic value elsewhere. Nanoparticles do interfere with the thrombo-static equilibrium. While this shift on one hand is a matter of concern, it may provide us a tool to handle or diagnose diseases in which such equilibrium is shifted. One of the finest models to test this dual aspect of the nano-scale objects is Acute Coronary Syndrome (ACS), a leading cause of death in the global scenario. What is known today regarding the effect of nanoscale objects may really be a tip of iceberg and with the advent of smarter nanoparticles one may think of more versatile use of nanotechnology in the management of ACS.

\section{Role of platelets in Acute Coronary Syndrome (ACS)}

ACS is a complex and multi-factorial disease (Badran et al., 2009). ACS is an umbrella like term which includes mainly three diseases i). ST elevated myocardial infarction (STEMI), ii). Non ST elevated myocardial infarction (NON STEMI), and iii) unstable angina. The patho-physiological event of ACS can be divided into four phases:

a. Atherosclerotic plaque formation.

b. Rupture of an unstable plaque.

c. The acute ischemic event.

d. Long term risk of recurrent coronary event.

\subsection{Platelet basic physiology}

Platelets play a pivotal in manifestation of ACS. Platelets are discoid in shape, with approximate number density $150,000-300,000 / \mu 1$, and dimension of the order of $2000-4000$ $\mathrm{nm}$. Derived from megakaryocyte (figure 1) (Thompson, 1986) they contain mitochondria, peroxisomes, endoplasmic reticulum. They also contain granules and glycogen bodies. 
Granules occur as i) dense granules ( $\delta$ ), ii) alpha granules (a). Dense granules mainly contains ATP, ADP, serotonin etc., whereas alpha granules contain fibronectin, fibrinogen, platelet activation factor (PAF) etc. (Marcus et al, 1966; Flaumenhaft et al, 2005). $\mathrm{Ca}^{++}$, one of the most important factors for platelet action, is stored in endoplasmic reticulum and released into the cytoplasm, during platelet activation (Nesbitt et al, 2003). Open canalicular system (OCS) is a channel like protrusion inside the platelet where granules release their contents (Escolar \& White, 1991). Recently role of mRNA and mi-RNA has been shown to play important roles in platelet aggregation (Calverley et al, 2010; Rowley et al, 2011; Nagalla et al, 2011).

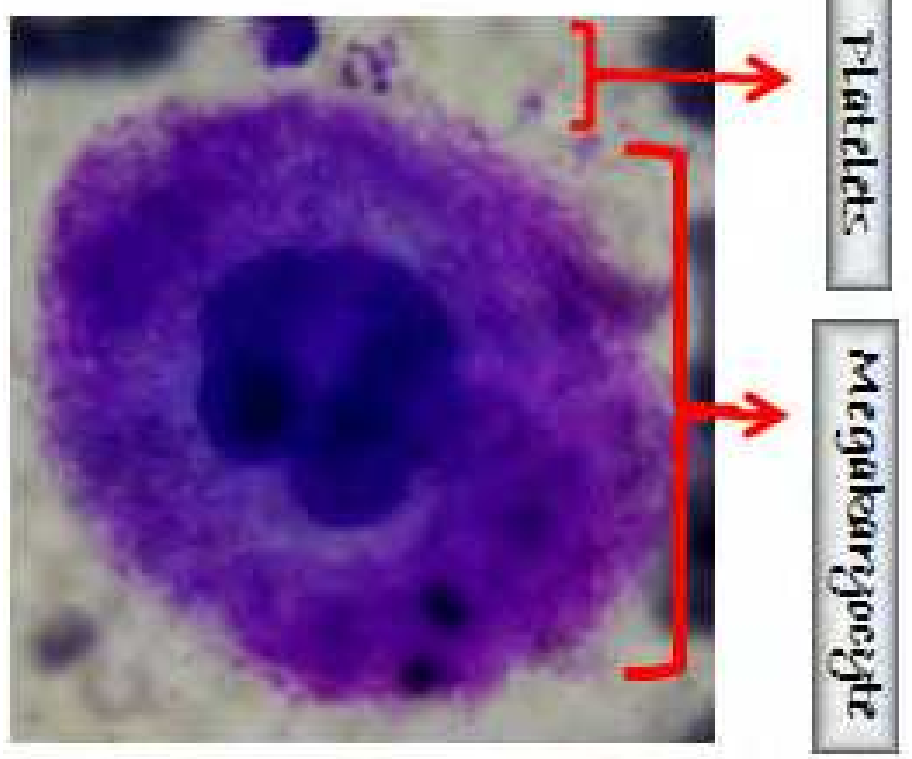

Fig. 1. Precursor megakaryocyte and progenitor platelets: Represents microscopic image (20X) of a megakaryocyte in the bone marrow. Platelets generated from the megakaryocyte can be seen in $12 \mathrm{o}^{\prime}$ clock position of the megakaryocyte.

When exposed to agonists, platelets become activated and this is followed by an aggregatory response (Patscheke, 1979). In systemic blood flow platelets remain in resting phase, without being activated (Marcus et al, 1991). Physiological agonists like collagen, thrombin, ADP, ATP etc. are not associated with the normal blood flow. Even if a trace amount of ADP and ATP are present, they are broken down by the phosphatase activity of CD39 (Marcus et al, 1997). At wound site, sub endothelial layers get ruptured. Hence Von Willebrand factor (vWf) and collagen get exposed causing activation of platelets (Nyman, 1980; Tschopp et al., 1980). After the primary phase of activation and aggregation, platelet granules are released, this leads to enhancement of local concentration of agonists (e.g. granule secreted ADP, ATP, serotonin etc.). This triggers irreversible secondary phase platelet aggregation with fibrinogen, which is further followed by cessation of bleeding (Decie and Lewis 2003) (figure 2). 


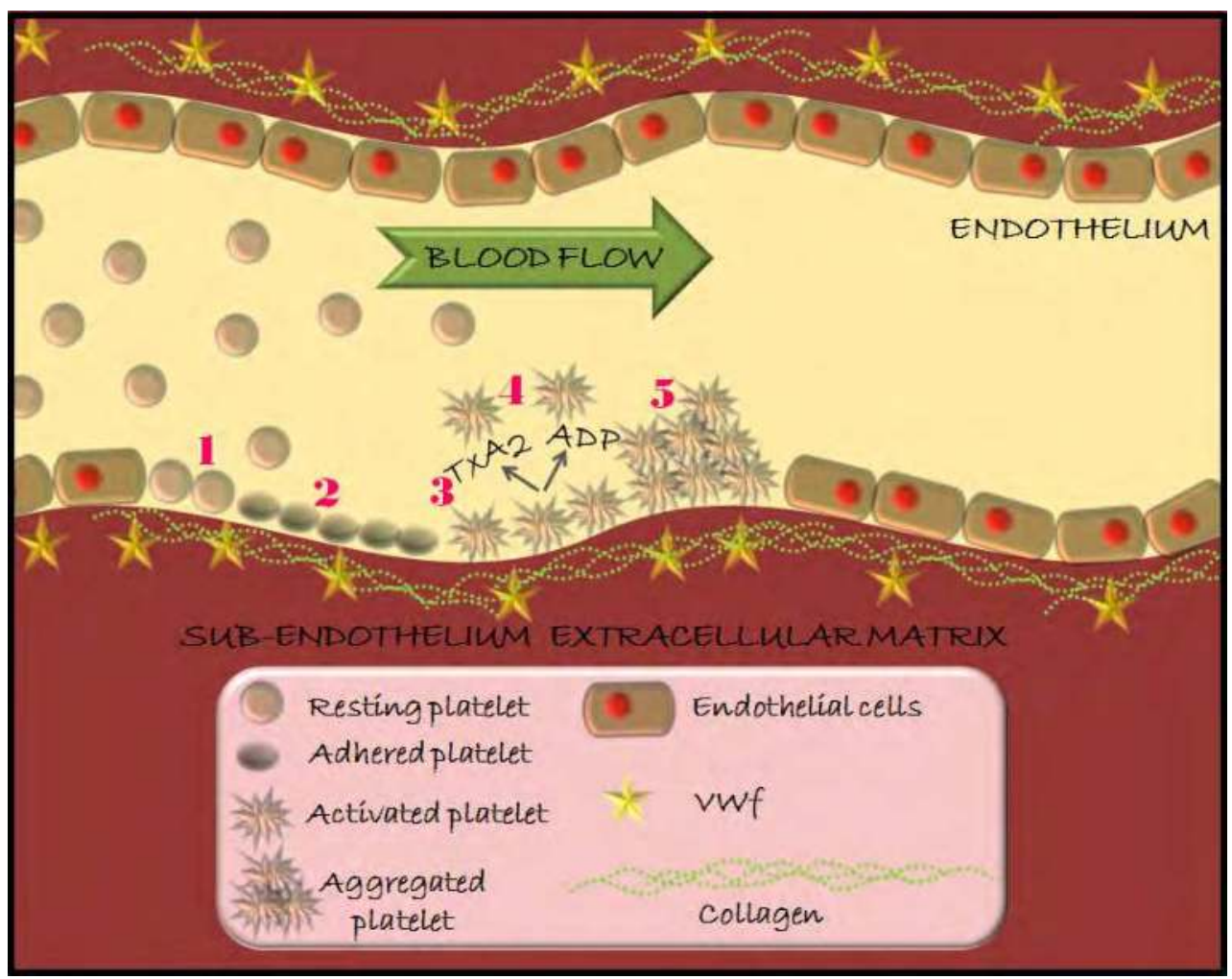

Fig. 2. Schematic diagram of platelet activation and aggregation. In the resting conditions platelets, maintain their discoid form and flow in circulation. Upon injury, platelets become exposed to sub-endothelial collagen and vWf (1) adhered on it (2). This is followed by activation and shape changes (3). The next phase is granules release and secondary phase aggregation (4) and lastly the stable platelet plaque forms(5).

The detailed mechanism of platelet function depends on the complex intracellular signalling pathways. This leads to platelet activation by simulating a series of physiological events. Briefly, after binding of agonists, the corresponding receptors trigger downstream signalling cascades and initiates $\mathrm{Ca}^{++}$mobilisation from endoplasmic reticulum. Platelet granules release ( $\alpha$ and $\delta$ ), platelet shape change and the thromboxane A2 (TXA2) production then follows. The cumulative effects of these events initiate activation of fibrinogen receptor (GPIIbIIIa) and triggering of primary phase aggregation. The released granules-content (ADP, ATP etc.) along with TXA2 activate other resting platelets resulting the secondary phase aggregation (Kroll \& Schafer, 1989; Ashby, 1990) (figure 3). The important signalling molecules that help the above process through a complex interplay among different Gprotein coupled receptors, integrin receptors, second messengers, kinases, phosphatise and $\mathrm{Ca}^{++}$mobilisation etc (Dorsam \& Kunapuli, 2004; Wu e al., 2006,2010; Roberts et al.,2004; Karniguian et al., 1990; Farndale, 2006; Spalding et al., 1998; Patscheke , 1980; Clifford et al., 1998; Hoffman et. al. 2009). 


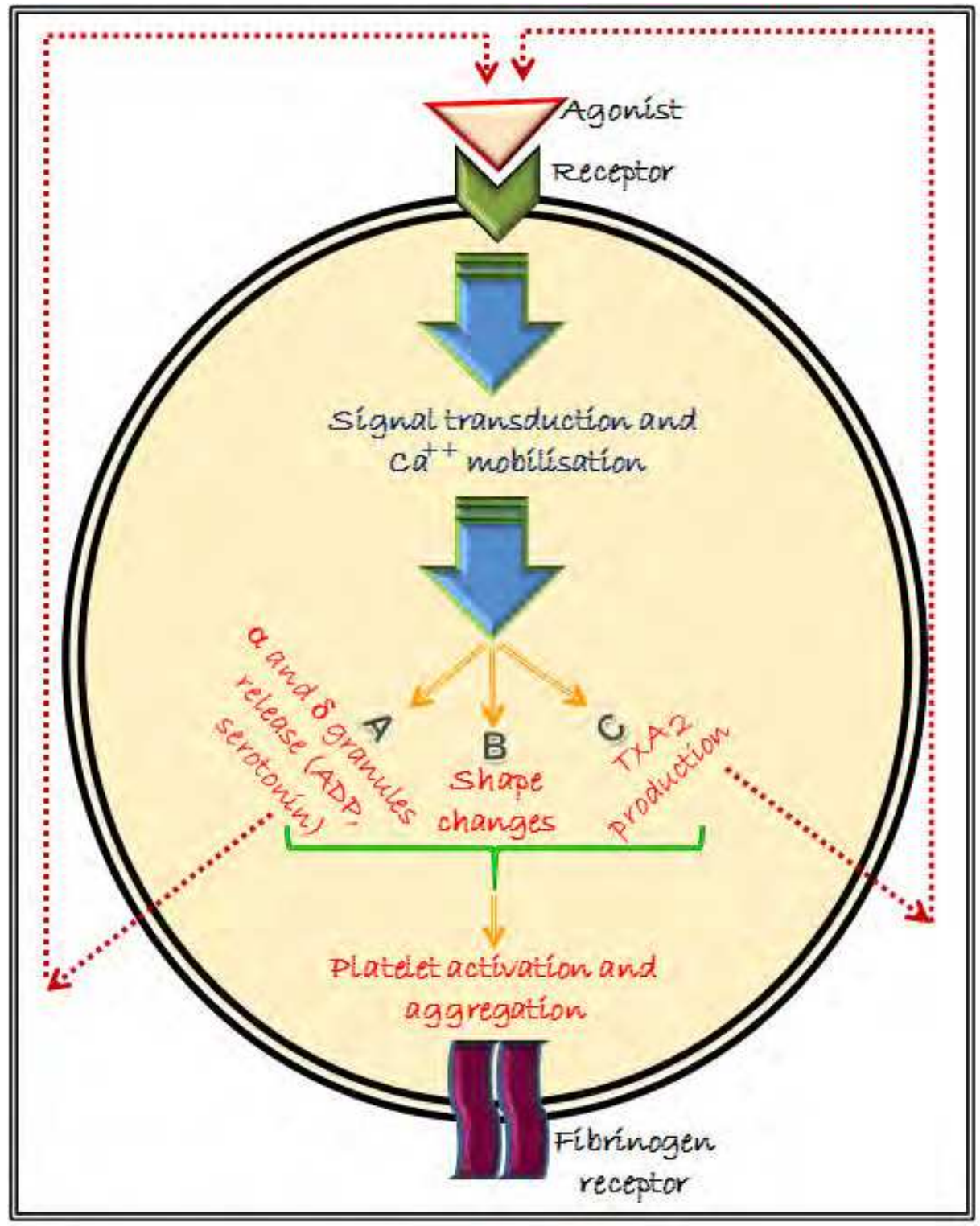

Fig. 3. Schematic diagram of agonists induced platelet activation. Binding of agonists with corresponding receptors, triggers downstream signalling cascade, and causes mobilisation of intracellular $\mathrm{Ca}^{++}$. The initial $\mathrm{Ca}^{++}$flux branches itself into three major signalling events: $\mathrm{A}$ (alpha and dense granules release), $\mathrm{B}$ (platelet shape change), $\mathrm{C}$ ( $\mathrm{TXA}_{2}$ production). The three signalling events cumulatively determine the activation and aggregation. The released chemicals (ADP,ATP etc) from granules and the TXA2, further activates other resting platelets and initiates the secondary phase of aggregation. 


\subsection{Platelet in ACS}

It may be contextual to focus on the pathological role of platelets in ACS. Platelet thrombosis plays a central role in the pathogenesis of Acute Coronary Syndrome (ACS) by the formation of thrombi at the site of the ruptured atherosclerotic plaque (figure 4) (Massberg et al., 2003; Kottke-Marchant, 2009; Lakkis et al., 2004).

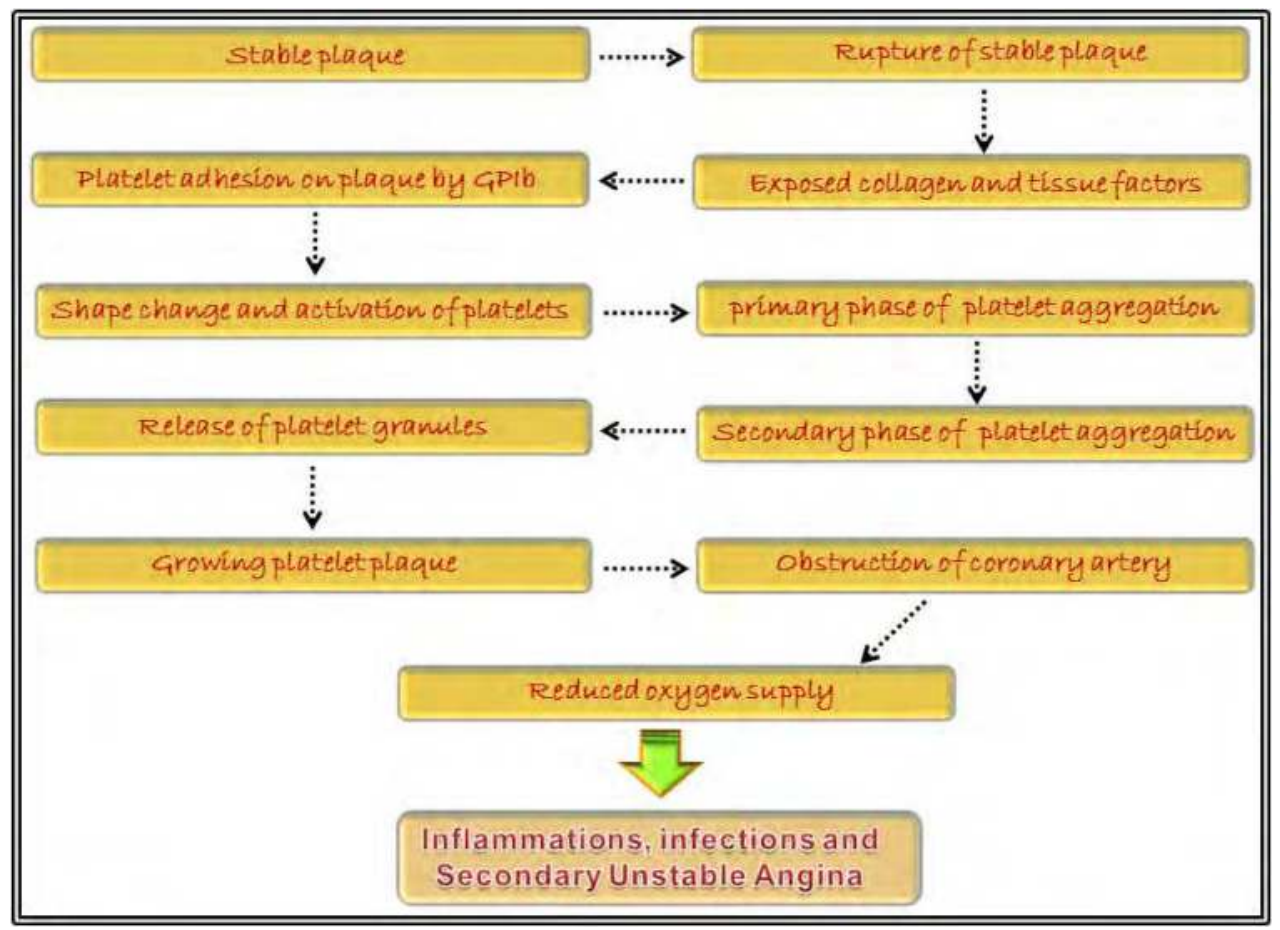

Fig. 4. Flow chart illustrating the role of platelets in thrombus formation.

Thus, the main therapeutic regime for the treatment of ACS is use of anti-platelet drug that inhibits platelet hyper aggregation (Faxon, 2011; Guha et al., 2009; Aragam \& bhatt, 2011; Born \& Patrono, 2006). Table 1 describes a list of such drugs, while their mode of action is illustrated in figure 5.

In the normal platelet aggregation process, downstream signalling induces fibrinogen receptor activation (GpIIbIIa). GpVI is the collagen receptor. P2X1 is the receptor of ATP and acts as $\mathrm{Ca}^{++}$channel. P2Y1 is high affinity ADP repector and P2Y12 is low affinity ADP receptor, where the former one is $\mathrm{G}_{\mathrm{q}}$ and the later one is $\mathrm{Gi}$ coupled. $\mathrm{Gz}$ coupled alpha $2 \mathrm{a}$ are adrenergic receptors for epinephrine, where $\mathrm{G}_{\mathrm{S}}$ coupled PGI2R are the receptors of prostaglandin $\mathrm{I}_{2}$ (PGI2) or prostaglandin E1 (PGE1), these being inhibitory receptors. Protease-activated receptor 1 (PAR1), protease-activated receptor 4 (PAR4), are coupled with $\mathrm{Gq}$ and $\mathrm{G}_{13}$ these being the receptors of thrombin. Thromboxane $A_{2}\left(T_{x} A_{2}\right)$ receptor $T P$ is also coupled with $G_{q}$ and $G_{13}$. Released TxA2 ( $b$ in figure 5) and ADP ( $a$ in figure5 ) further act on their corresponding receptors. The second messengers and other signalling mediators include, (DAG) diacylglycerol; (PLC $\beta$ ) phospholipase $C \beta$; $(\mathrm{PKC})$ protein kinase $\mathrm{C}$; $\left(\mathrm{PIP}_{2}\right)$ 


\begin{tabular}{|ll|}
\hline \multicolumn{1}{|c}{ Mode of Action } & \multicolumn{1}{c|}{ Name of the drugs } \\
\hline Cyclo-oxygenase inhibitors (COX1), (1) & Aspirin \\
\hline P2Y12 receptor inhibitors(2) & Clopidogrel, Prasugrel, Ticlopidine \\
\hline Phosphodiestarase inhibitors(3) & Cilostazole \\
\hline Glycoprotein GPIIbIIIa inhibitors(4) & Abciximab, Eptifibatide, Tirofiban \\
\hline Adenosine uptake inhibitors(5) & Dipyridamole \\
\hline
\end{tabular}

Table 1. List of anti-platelet drugs - their mode of action and generic names. The most common drugs are described in the first two rows.

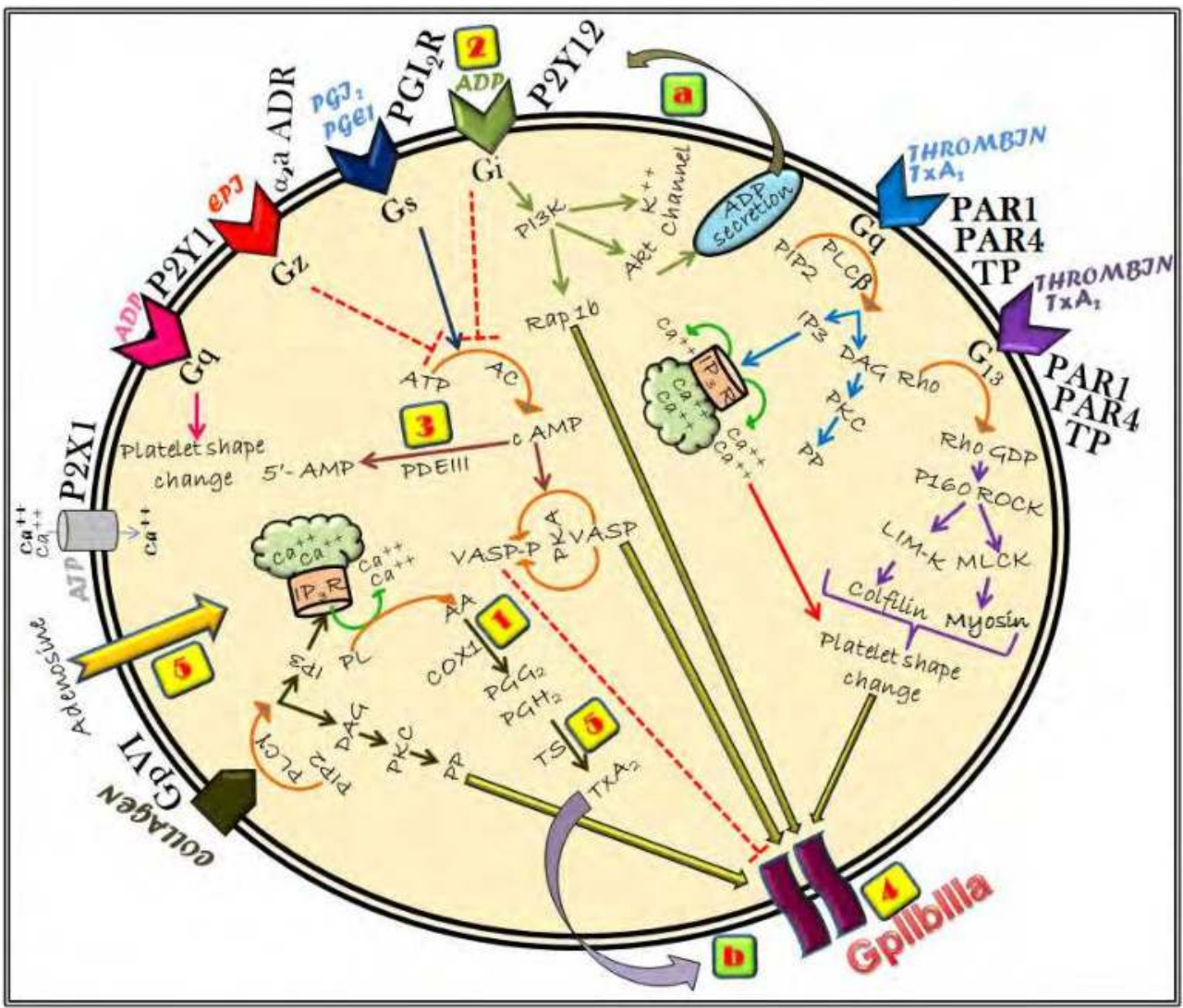

Fig. 5. Target sites for anti-platelet drugs in platelet signalling pathway- different downstream signalling pathways are shown. The drug targets described in Table 1 are represented by the corresponding numbers (see text for elaboration). 
phosphotidylinositol-4,5-biphosphate; $\left(\mathrm{PLC}_{\gamma}\right)$ phospholipase $\mathrm{C}_{\gamma} ;\left(\mathrm{PLC}_{\beta}\right)$ phospholipase $\mathrm{C} \gamma$; $\left(\mathrm{IP}_{3}\right)$ inositol triphosphate; $\left(\mathrm{IP}_{3} \mathrm{R}\right)$ inositol triphosphate receptor; (PP) protein phosphorylation; ( $\mathrm{PLA}_{2}$ ) Phospholipase $\mathrm{A}_{2}$; (AA) arachidonic acid; AkT and Rap1B (which are serine /threonine kinase), (PI3K) phosphatidylinositol 3-kinase; (AC) adenylyl cyclase; (PKA) phosphokinase A; (cAMP) cyclic adenosine mono phosphate; (VASP) vasodialator stimulated phosphor protein; (P160 ROCK) a Rho activated kinase, (MLCK) myosine light chain kinase, (LIM-K) LIM kinase; (PGG2) prostaglandin G2; (PGH2) prostaglandin H2; (PL) membrane phospholipids; (COX1) cyclooxygenase 1; (TS) thromboxane synthetase and (PDEIII) phosphor di-esterase III. As platelets are the key player in ACS, any extraphysiological environmental materials that can alter platelet signalling circuit is of great challenge in combating the disease. This is the context where nanotechnology can come in picture.

\section{Nano-interface}

Nanotechnology has the potential to interfere with basic biological mechanisms because of their tunable electrical, magnetic and optical properties, and small size ( Chen et al., 2005; Gobin et al., 2007; Fu et al., 2007). This tunability makes them potential tool in diagnostics (e.g. bio-imaging) therapy and a smart combination of both of these properties (Smith et al., 2008; Peng et al., 2000; Li et al., 2003; Murry et al., 2000).

Some of advancement of nanotechnology inspired application include improved imaging contrast agents by SPIONS (super-paramagnetic iron oxide nanoparticles), targeted delivery of drugs, molecular chaperons and agents to kill specific cancer cells ( $\mathrm{Yu}$ et al., 2011; Petkar et al., 2011; Patra et al., 2007). Another exclusive application involve magnetic induction (radio frequency) heating or laser induced heating of designer particles, with desirable material and shape attributes (Peterman et al., 2003; Plech et al., 2004). The hyperthermic killing of tumor cells, is one of the most important examples (Rao et al., 2010; Huff et al., 2007). The recently reported chaperon properties of nanoparticles can also have important biomedical potential (Singha et al., 2010). Interestingly there are only few report on haematological (Elias \& Tsourkas 2009; Baker, 2009; Walkey et al., 2009; Wickline et al., 2005) and cardiological applications (Lanza et al., 2006; Iverson et al., 2008) of nanotechnology.

\section{Nanotechnology in ACS and platelet contexts}

Nanotechnology is important in ACS because of several reasons. A simple application is imaging of plaques, conventional methods being grossly inadequate for such purpose (Nikolas, 2009; Wicklinea \& Lanza, 2003). Secondly, the targeted delivery of therapeutic agents using nanoparticles to the areas of injured or dysfunctional vascular wall that inhibit the plaque progression is of significant importance in the ACS context (Nikolas, 2009).

Furthermore, nanoparticle based assay can be used for the detection of myocardial injury in patients with ACS (Wilson et al., 2009). In the therapeutic regime, an important use of nanotechnology is to increase the amount of HDL in circulation interning delivery of cholesterol to liver, thus minimizing the risk associated with ACS (Luthi et al., 2010). 


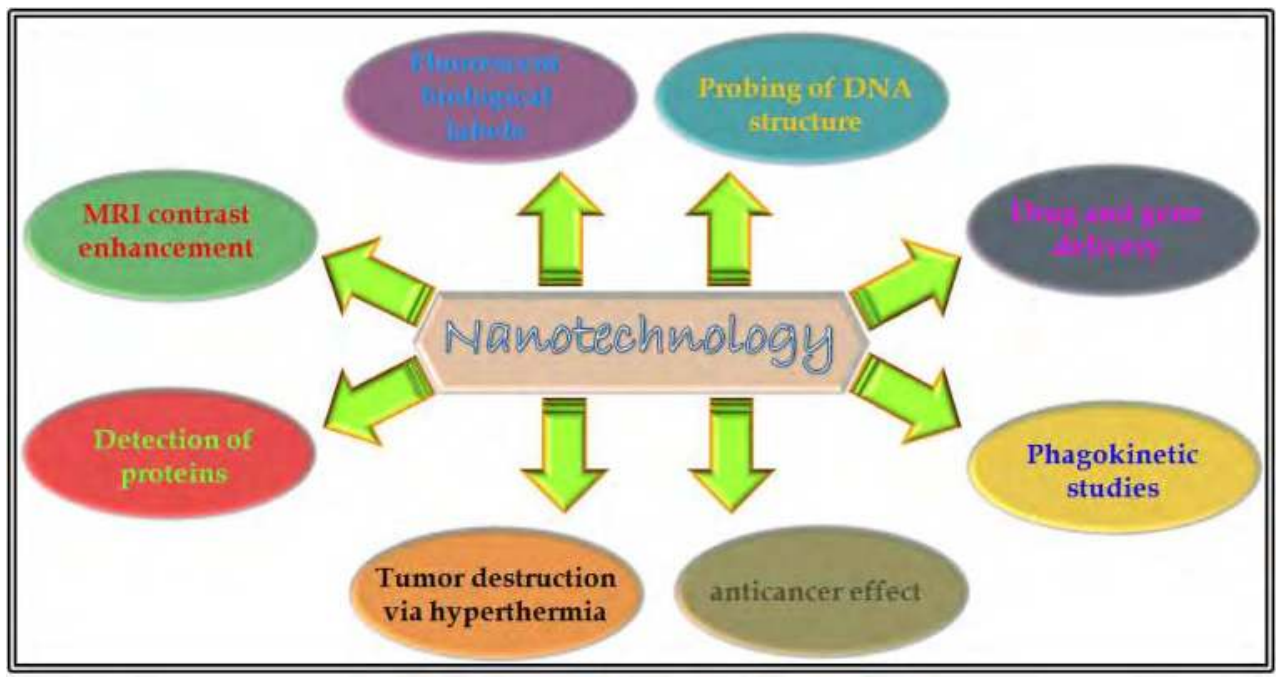

Fig. 6. Diverse applications in nanotechnology

In most of the above mentioned cases (diagnosis, drug delivery or treatment) the primary entry route of nanoparticle is through circulation where they interact directly with blood cells. Conversely exposure to unwanted nanoparticles (e.g. gas phase exhaust from car or industry ) inhaled by human, that can penetrate the alveolar space and interfere with circulation may lead to cardiovascular diseases ( Yamawaki \& Iwai, 2006; Mohmmad et al., 2011; Chen et al., 2008). In both cases such interaction deserves a special attention.

In case of ACS patients, if nanoparticles activate platelets then they may induce life threatening alarm. Till now there are a number of papers (Geys et al., 2008; Oberdörster et al., 2007; Deb et al., 2007,2011; Wiwanitkit et al., 2009; Radomski et al., 2005; Shrivastava et al., 2009; Koziara et al., 2005; Mayer et al., 2009; Li et al., 2009; Ramtoola et al., 2010; McGuinnes et al., 2010; Nemmar et al., 2003; Gulati et al., 2010; Cejas et al., 2007; Wilson et al., 2010; Rückerl et al., 2007) about the effect of nanoparticles on platelets (Table. 2.) where most of the citations show that nanoparticles can induce platelet aggregation. What makes a nanoparticle pro-aggregarory (Geys et al., 2008; Oberdörster et al., 2007; Deb et al., 2007,2011; Wiwanitkit et al., 2009; Radomski et al., 2005; Mayer et al., 2009; McGuinnes et al., 2010; Nemmar et al., 2003; Cejas et al., 2007; Wilson et al., 2010; Rückerl et al., 2007; Miller et al., 2009), inert (Li et al., 2009; Ramtoola et al., 2010; Gulati et al., 2010) or even anti-platelet in nature (Shrivastava et al., 2009; Koziara et al., 2005; Miller et al., 2009) is of great importance in development of ACS based nano-drugs, risk assessment in ACS, and also in evaluating resistance to ACS related drugs (Guha et al., 2009; Jogns et al., 2006; Michelson et al., 2006). 


\begin{tabular}{|c|r|r|}
\hline & TYPE OF NANOMATERIALS & EFFECT ON \\
\hline PLATELETS
\end{tabular}

Table 2. Nanoparticle effects on platelets - the Table enlists how the platelet response varies with variation in nano-material as well as the corresponding nano-surface configuration. NP is nanoparticle.

\section{Platelet nanoparticle interaction - A deeper insight}

A different paradigm of nanotechnology application has recently got considerable interest. How thrombotic response is modulated by nanoparticles has recently become a new paradigm in nano-medicine. Till today, the exact mechanisms of how nano-surface exposure or uptake of nanoforms alter the platelet response are not known. Most of the metallic nanoparticles, carbon nanoparticles, aerosol and polymer nanoparticles induce platelet aggregation (Mayer et al., 2009; McGuinnes et al., 2011). A few nanoparticles remain inert for platelet or induce antiplatelet effect (Li et al., 2009; Ramtoola et al., 2010; Gulati et al., 2010). Interestingly in case of some polymer nanoparticles, surface conjugation induces varying response to platelets (McGuinnes et al 2010). One needs deeper insights in induced platelet signalling to explain such varying response to nanoparticles with a characteristic surface property. 
As mentioned earlier, anti-platelet drug therapy is the most important therapeutic regime for ACS patients. A major fall-out of the conventional therapeutic approach is the sizable incidence of drug resistance among ACS patients (Guha et al., 2009; Jogns et al., 2006; Michelson et al., 2006). There are indications that nanotechnology can help diagnosis of drug resistance (Deb et. al. 2011).

Again, metallic nanoparticles can induce platelet aggregation depending on the physiological state of the platelets. For a given nano-drug such response can show inter individual variations, and there is evidently a scope of judging the safety of such drugs depending on the extent of induced alteration in platelet function. It may be important to note that under certain conditions nanoparticles can be hazardous to both normal individuals as well as ACS patients. Table 3 summarises the overall ACS risk associated with nanoparticles:

\begin{tabular}{ll}
\hline \multicolumn{1}{|c}{ Phenomenon } & \multicolumn{1}{c|}{ Risk Factors } \\
\hline$<60 \mathrm{~nm}$ nanoparticle. & Safe in context to thrombotic risk. \\
\hline $\begin{array}{l}\text { Resting platelets + nanoparticle. } \\
\begin{array}{l}\text { Anti-platelet drug like clopidogrel or reo- } \\
\text { pro. }\end{array}\end{array}$ & No thrombotic risk. \\
\hline $\begin{array}{l}\text { Rupture plaque (where vascular bed is } \\
\text { open) + Nanoparticle of any size. }\end{array}$ & High thrombotic risk. \\
\hline \begin{tabular}{l} 
Some special surface modification \\
\hline
\end{tabular} & tunable \\
\hline
\end{tabular}

Table 3. Overview of thrombotic risk factors of nanoparticles.

\subsection{Excitability of the nanoparticle mediated pro-aggregatory response}

Metallic nanoparticle (made of gold, copper, iron, cadmium sulphide and quantum dots) induced platelet aggregation is intriguing as the profile change of such aggregation fully depends on the physiologic conditions of the platelets (e.g. pre-activation) (Deb et al., 2007, 2011; Geys et al., 2008). Non-metallic carbon nano-tube or polymer based nanoparticles on the other hand induce platelet aggregation without any pre-activation, their proaggregatory effect depends mainly on hydrophobic collapses (Radomski et al., 2005) or charge-charge interaction among platelets and nanoparticles (McGuinnes et al., 2010). At critical concentrations of ADP or in presence of a threshold shear force, which mildly activates the platelets, they become most sensitive to nano-particles (figure 7). In other words, the nanoparticles in such cases serve as agonists. On the other hand, when platelets are in resting condition most of the metallic nano-forms seems to be inert.

Unlike optimal size response (of nanoparticles) observed in case of cancer cells, the nanoresponse in platelets increases monotonically with decreasing size of nanoparticles (Deb et al., 2011). This phenomenon occurs also in case of polystyrene nanoparticles (Mayer et al., 2009). This size attribute is similar to entry of the nanoparticles through inhalation. Smaller the size of the nanoparticle, lesser in the efficiency of the clearance by alveolar macrophages, which in turn increases their (nanoparticle) deposition in alveolar cell leading to entry into 
circulation (Yamawaki \& Iwai, 2006). Thus, smaller nanoparticles pose a higher risk in the ACS scenario.

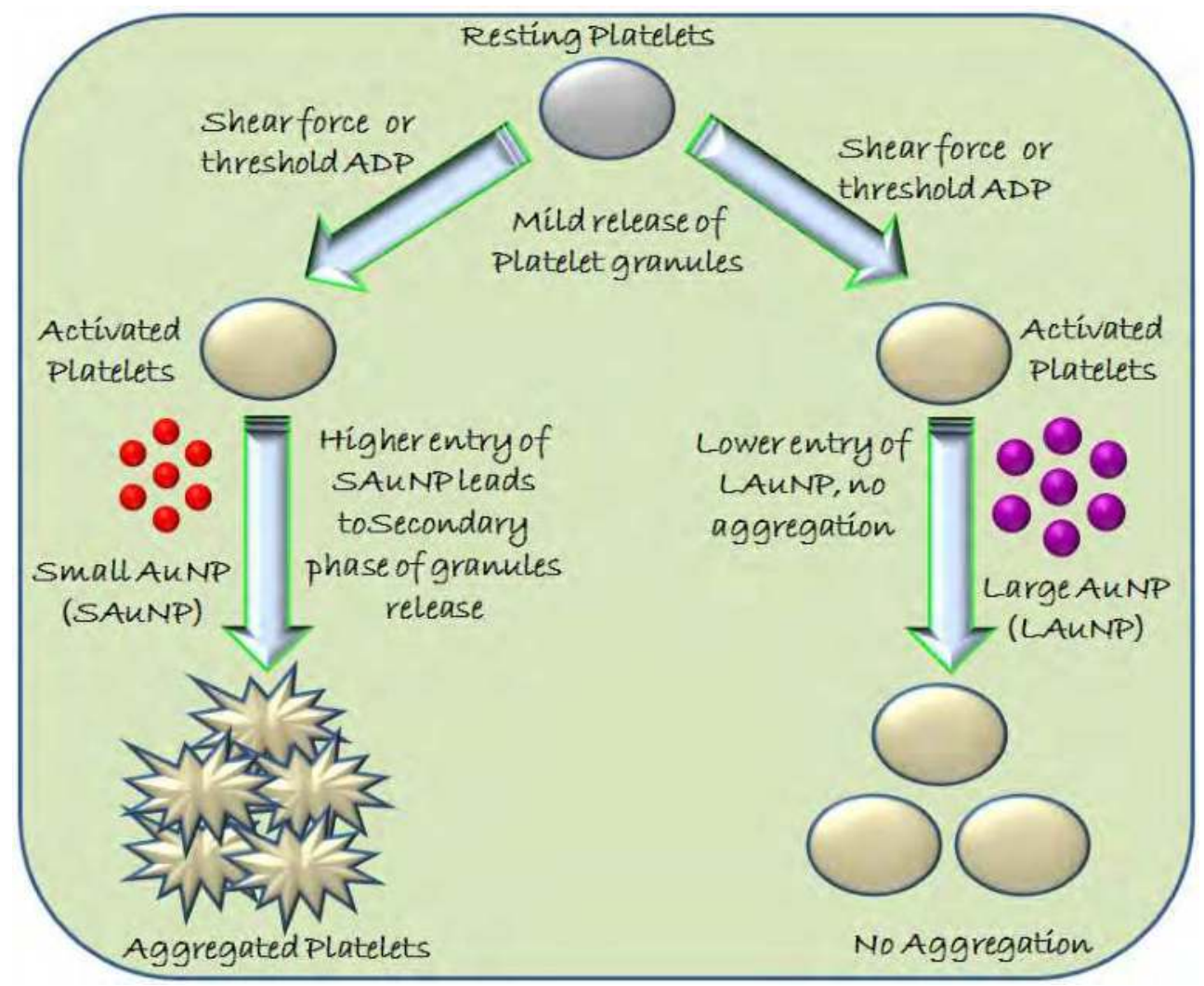

Fig. 7. Nanoparticle Size Response. Gold Nanoparticle induced platelet response [see Deb et. al. 2007,2011] is dependent on nanoparticle size, smaller particle showing aggregatory effects.

Though the exact molecular mechanism of metallic-nanoparticle platelet interaction is yet to be established, systemic response like release of platelet granules (both a and $\delta$ ) have been observed in presence of nano-particles. In presence of apyrase (scavenge ADP released from $\delta$ granules), or anti-platelet drug clopidogrel (block P2Y12 purinergic receptors, thus inhibit secondary wave of aggregation, which is the signature of granules release) nano-particle induced aggregation inhibited. In presence of Arg-Gly-Asp-Ser (RGDS) (a tetra-peptide, which binds to fibrinogen receptor GpIIbIIIa, mimicking the anti-platelet drug Reo-Pro), nano induced platelet aggregation is again inhibited. This reflects that nanoparticles induced aggregation is not due to any physico-chemical agglomerate formation. Consequently, metallic nano-forms are unlikely to activate platelets from patients under anti-platelet drug therapy (Deb et al., 2011). Alternatively, conjugation of anti-platelet drugs (or combined administration of such drugs) can help to reduce the thrombotic risk of nanoparticle based drug formulation. 


\subsection{Platelet Response as a measure for nano-safety}

In the suspended condition, metallic nanoparticle induced platelet aggregation is highly dependent on the local ADP concentration. A transition of deaggregation to aggregation occurs at a threshold concentration of ADP. Interestingly, nanoparticle effect is most pronounced at this threshold concentration (Deb et al., 2007). This threshold nano-response is perhaps a manifestation of primary triggering of granules release which undergoes an auto-catalysis, ultimately leading to aggregation.

As there is a considerable variation of platelet aggregation among individuals, the threshold ADP concentration and extent of enhancement of aggregation induced by the nanoparticle have an individual specific fingerprint. The parameters thus can be used as nano-safety indices. Higher the threshold value and lower the nanoparticle induced aggregation, safer is the nano-drug (Deb et al., 2011).

\subsection{Nanoparticles and antiplatelet drugs}

Aspirin and Clopidogrel are most widely used anti-platelet drugs for ACS .In many cases dual antiplatelet drug (both Aspirin and Clopidogrel) therapy is used for patient safety (Born et al, 2006, Guha et al., 2009, Faxon 2011, Aragam et al., 2011) Despite the benefits of dual antiplatelet therapy, many patients still suffer from cardiovascular disease due to resistance to such drugs. The drug resistance also increases the risk of the recurrent occurrence of ACS (Guha et al., 2009; Jogns et al., 2006; Michelson et al., 2006). It is thus important to have a quick sensor that will assess the resistance to aspirin or clopidogrel in patients in one step and also assess the equivalence of the drug effects with respect to variations in geographic populations (which may correspond to genetic variations of patient population) and variations in effective drug dose among different drug manufacturers (Deb et al., US patent application, 2011).

Interestingly among the ACS patients, one's showing resistance to the conventional antiplatelet drugs (e.g. aspirin or clopidogrel) respond differentially to gold nanoparticle $(\sim 20 \mathrm{~nm})$ as compared to one's responding to it. This differential response can be used as a convenient classifier of responders and non responder to antiplatelet drugs (see figure 8).

\subsection{Nano-material nano-surface and nano-response}

Though most of the nano induced response is pro-aggregatory in nature, a few reports Mention inert nature of some nanoparticles (Li et al., 2009; Ramtoola et al., 2010; Gulati et al., 2010). As most of the nano-particles induce platelet aggregation, so it can be said the aggregatory nature of nano surface depends on its diameter rather than its component material. But this conjecture is not applicable to all nano-forms. Charged surface (aminated positively charged or carboxylated - negatively charged) polystyrene latex nano-forms are capable of inducing platelet aggregation, whereas unmodified latex beads are unable to do so. Interestingly, the modes of aggregation for positive and negatively charged nanoparticles are different. For carboxylated nanoparticle the aggregation is due to the upregulation of surface adhesion molecules, whereas aminated nanoparticles alter the platelet membrane and interact with the anionic phospholipid (Mayer et al., 2009; McGuinnes et al., 2010). Though both of the charged particles are capable of inducing platelet aggregation, the negatively charged larger particles (larger than 60nm) are shown to be less toxic in the platelet activation context (Mayer et al., 2009).The lesser toxicity of the such particle is probably due to less entry and charge repulsion between nano particles and platelets. Human cell derived nanoparticles that actually accentuate platelet granules 
release, inhibit platelet aggregation. This paradox is possibly due to the reduction of platelet-platelet interaction in presence of nanoparticle (Miller et al., 2009). Negatively charged Polyethylene glycol (PEG) coated nanoparticles from Microemulsion precursor (PEG-E78) induces platelet inhibition (Koziara et al., 2005). Importantly, in both proaggregatory or antiplatelet responses, the nanoparticles are effective inducer when added in the pre-incubation stage. Neither the inhibition nor the aggregatory response are observed once the aggregation is initiated by an agonist (Koziara et al., 2005; Deb et al. 2007, 2010). Similar argument holds good for anti-platelet effect of silver nanoparticles prepared with a certain surface attributes (Shrivastava et al., 2009). Silver nanoparticles with a different surface conjugations again show pro-aggregatory effects (Deb et al., 2011 (in press)).

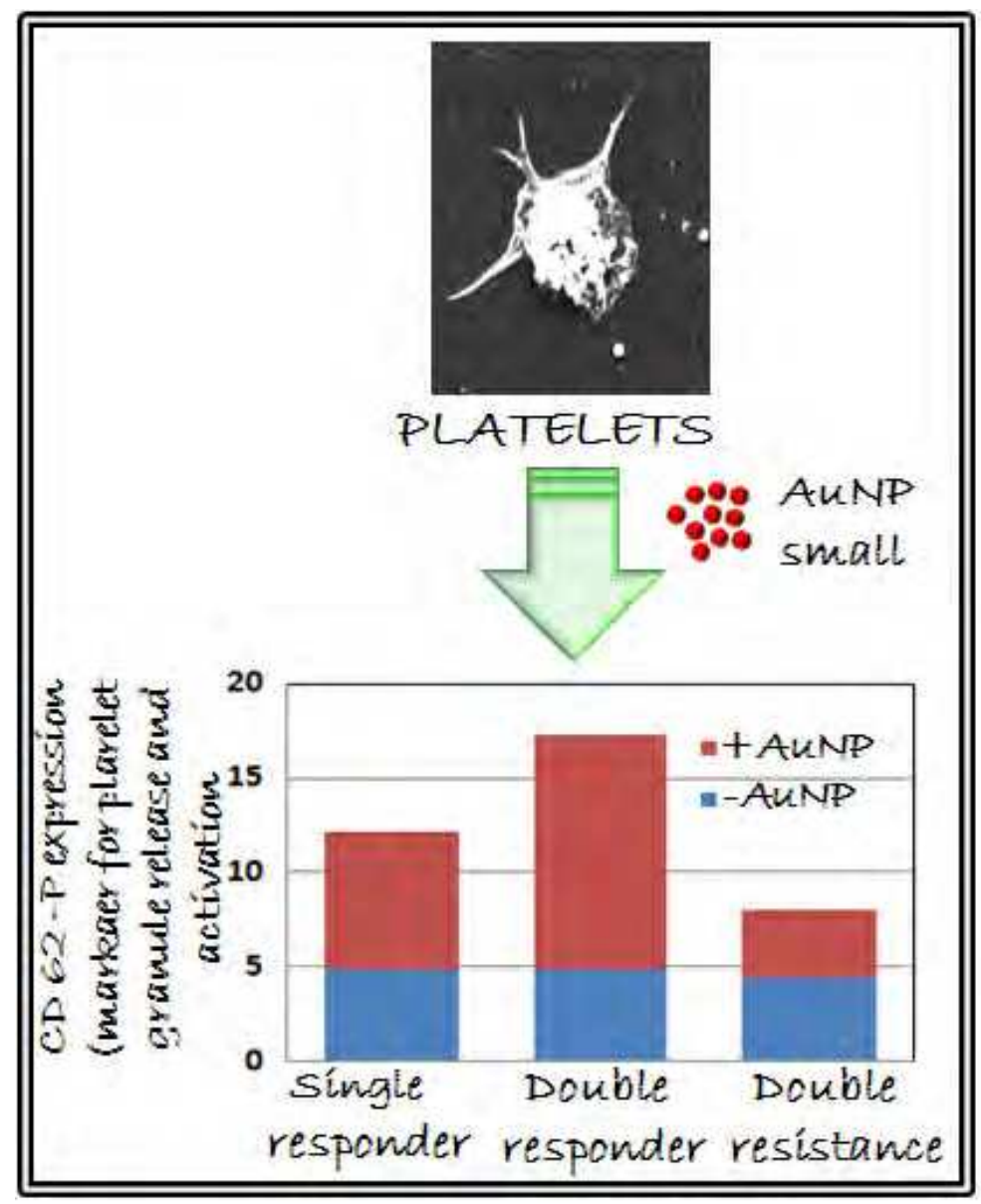

Fig. 8. Nanosensor for Drug Resistance in ACS [89]-Using Nanoparticle effect to discriminate between responder and non-responder of antiplatelet drugs (e.g. aspirin and clopidogrel).

The important question that crops up here is whether in the platelet context it is the nanosurface conjugation or the nano-material that play the lead role. It follows that by modulating 
the nano-surface, one can tune the thrombotic level, the desirable level depending on the patient status. For ACS, the desired state is a nanoform that attenuates the aggregatory response, and in case of hemorrhage the situation may be complimentary in nature.

\section{References}

Aragam KG, Bhatt DL. Antiplatelet therapy in acute coronary syndromes.J Cardiovasc Pharmacol Ther. 2011 Mar;16(1):24-42. Epub 2010 Oct 5.

Arnida, Malugin A, Ghandehari H. Cellular uptake and toxicity of gold nanoparticles in prostate cancer cells: a comparative study of rods and spheres.J Appl Toxicol. 2010 Apr;30(3):212-7.

Ashby B, Daniel JL, Smith JB. Mechanisms of platelet activation and inhibition.Hematol Oncol Clin North Am. 1990 Feb;4(1):1-26.

Badran HM, Elnoamany MF, Khalil TS, Eldin MM.Age-related alteration of risk profile, inflammatory response, and angiographic findings in patients with acute coronary syndrome.Clin Med Cardiol. 2009 Feb 18;3:15-28.

Baker JR Jr. Dendrimer-based nanoparticles for cancer therapy.Hematology Am Soc Hematol Educ Program. 2009:708-19.

Born G, Patrono C.Antiplatelet drugs.Br J Pharmacol. 2006 Jan;147 Suppl 1:S241-51.

Calverley DC, Phang TL, Choudhury QG, Gao B, Oton AB, Weyant MJ, Geraci MW. Significant downregulation of platelet gene expression in metastatic lung cancer.Clin Transl Sci. 2010 Oct;3(5):227-32.

Cejas MA, Chen C, Kinney WA, Maryanoff BE. Nanoparticles that display short collagenrelated peptides. Potent stimulation of human platelet aggregation by triple helical motifs.Bioconjug Chem. 2007 Jul-Aug;18(4):1025-7. Epub 2007 Jun 21.

Chen J, Saeki F, Wiley BJ, Cang H, Cobb MJ, Li ZY, Au L, Zhang H, Kimmey MB, Li X, Xia Y. Gold nanocages: bioconjugation and their potential use as optical imaging contrast agents. Nano Lett. 2005 Mar;5(3):473-7.

Chen Z, Meng H, Xing G, Yuan H, Zhao F, Liu R, Chang X, Gao X, Wang T, Jia G, Ye C, Chai $\mathrm{Z}$, Zhao $\mathrm{Y}$. Age-related differences in pulmonary and cardiovascular responses to $\mathrm{SiO} 2$ nanoparticle inhalation: nanotoxicity has susceptible population. Environ Sci Technol. 2008 Dec 1;42(23):8985-92.

Chithrani BD, Ghazani AA, Chan WC. Determining the size and shape dependence of gold nanoparticle uptake into mammalian cells.Nano Lett. 2006 Apr;6(4):662-8.

Clifford EE, Parker K, Humphreys BD, Kertesy SB, Dubyak GR.The P2X1 receptor, an adenosine triphosphate-gated cation channel, is expressed in human platelets but not in human blood leukocytes.Blood. 1998 May 1;91(9):3172-81.

Deb S, Chatterjee M, Bhattacharya J, Lahiri P, Chaudhuri U, Pal Choudhuri S, Kar S, Siwache O P, Sen P, Dasgupta A K.Role of purinergic receptors in plateletnanoparticle interactions.Nanotoxicology 2007. 1:93-103.

Deb S, Patra HK, Lahiri P, Dasgupta AK, Chakrabarti K, Chaudhuri U. Multistability in platelets and their response to gold nanoparticles. Nanomedicine. 2011 Feb 26. [Epub ahead of print]

Deb S, Dasgupta AK. One step nanosensor for single and multidrug resistance in acute coronary syndrome (acs).Pub No: US 2011/0053172 A1

Deb S, Raja SO, Dasgupta AK, Sarkar R, Chattopadhyay AP, Chaudhuri U, Guha P, Sardar $\mathrm{P}$. Surface tunability of nanoparticles in modulating platelet functions. Blood Cells, Molecules, and Diseases. 2011 [in press]. 
Decie and Lewis. Practical Heamatology. 9th edition. Edited by S M Lewis, B J Bain, I Bates. Chapter 16 - Investigation of Haemostasis.

Dorsam RT, Kunapuli SP. Central role of the P2Y12 receptor in platelet activation.J Clin Invest. $2004 \mathrm{Feb} ; 113(3): 340-5$.

Elias A, Tsourkas A. Imaging circulating cells and lymphoid tissues with iron oxide nanoparticles.Hematology Am Soc Hematol Educ Program. 2009:720-6.

Escolar G, White JG.The platelet open canalicular system: a final common pathway.Blood Cells. 1991;17(3):467-85; discussion 486-95.

Farndale RW. Collagen-induced platelet activation.Blood Cells Mol Dis. 2006 MarApr;36(2):162-5. Epub 2006 Feb 7.

Faxon DP. Optimizing antiplatelet therapy in acute coronary syndrome and percutaneous coronary intervention.Catheter Cardiovasc Interv. 2011 May 26. doi: 10.1002/ccd.23163. [Epub ahead of print]

Flaumenhaft R, Dilks JR, Rozenvayn N, Monahan-Earley RA, Feng D, Dvorak AM. The actin cytoskeleton differentially regulates platelet alpha-granule and dense-granule secretion. Blood. 2005 May 15;105(10):3879-87. Epub 2005 Jan 25.

Fu A, Gu W, Boussert B, Koski K, Gerion D, Manna L, Le Gros M, Larabell CA, Alivisatos AP. Semiconductor quantum rods as single molecule fluorescent biological labels. Nano Lett. 2007 Jan;7(1):179-82.

Geys J, Nemmar A, Verbeken E, Smolders E, Ratoi M, Hoylaerts MF, Nemery B, Hoet PH. Acute toxicity and prothrombotic effects of quantum dots: impact of surface charge. Environ Health Perspect. 2008 Dec;116(12):1607-13. Epub 2008 Jul 18.

Gobin AM, Lee MH, Halas NJ, James WD, Drezek RA, West JL. Near-infrared resonant nanoshells for combined optical imaging and photothermal cancer therapy. Nano Lett. 2007 Jul;7(7):1929-34. Epub 2007 Jun 6.

Guha S, Mookerjee S, Guha P, Sardar P, Deb S, Roy PD, Karmakar R, Mani S, Hema MB, Pyne S, Chakraborti P, Deb PK, Lahiri P, Chaudhuri U.Antiplatelet drug resistance in patients with recurrent acute coronary syndrome undergoing conservative management.Indian Heart J. 2009 Jul-Aug;61(4):348-52.

Guha S, Sardar P, Guha P, Deb S, Karmakar R, Chakraborti P, Mookerjee S, Deb PK, De R, Dutta A, Chaudhuri U. Dual antiplatelet therapy in ACS: time-dependent variability in platelet aggregation during the first week.Indian Heart J. 2009 Mar-Apr;61(2):173-7.

Guha S, Sardar P, Guha P, Roy S, Mookerjee S, Chakrabarti P, Deb PK, Chaudhuri U, Deb S, Karmakar R, Dasgupta AK, Lahiri P.Dual antiplatelet drug resistance in patients with acute coronary syndrome.Indian Heart J. 2009 Jan-Feb;61(1):68-73.

Gulati N, Rastogi R, Dinda AK, Saxena R, Koul V. Characterization and cell material interactions of PEGylated PNIPAAM nanoparticles.Colloids Surf B Biointerfaces. 2010 Aug 1;79(1):164-73. Epub 2010 Apr 10.

Hoffman R, Edward J. Benz Jr et.al.Hematology Basic Principles and Practice. Edition 5. Chapter116 - The Molecular Basis of Platelet Activation 2009.

Huff TB, Tong L, Zhao Y, Hansen MN, Cheng JX, Wei A.Hyperthermic effects of gold nanorods on tumor cells.Nanomedicine (Lond). 2007 Feb;2(1):125-32.

Iverson N, Plourde N, Chnari E, Nackman GB, Moghe PV. Convergence of nanotechnology and cardiovascular medicine : progress and emerging prospects.BioDrugs. 2008;22(1):1-10.

Johns A, Fisher M, Knappertz V. Aspirin and clopidogrel resistance: an emerging clinical entity.Eur Heart J. 2006 Jul;27(14):1754; author reply 1754-5. Epub 2006 Jun 2.

Karniguian A, Grelac F, Levy-Toledano S, Legrand YJ, Rendu F. Collagen-induced platelet activation mainly involves the protein kinase C pathway. Biochem J. 1990 Jun 1;268(2):325-31. 
Kottke-Marchant K. Importance of platelets and platelet response in acute coronary syndromes.Cleve Clin J Med. 2009 Apr;76 Suppl 1:S2-7.

Koziara JM, Oh JJ, Akers WS, Ferraris SP, Mumper RJ. Blood compatibility of cetyl alcohol/polysorbate-based nanoparticles. Pharm Res. 2005 Nov;22(11):1821-8. Epub 2005 A

Kroll MH, Schafer AI.Biochemical mechanisms of platelet activation.Blood. 1989 Sep;74(4):1181-95.

Lakkis N, Dokainish H, Abuzahra M, Tsyboulev V, Jorgensen J, De Leon AP, Saleem A. Reticulated platelets in acute coronary syndrome: a marker of platelet activity.J Am Coll Cardiol. 2004 Nov 16;44(10):2091-3.

Lanza G, Winter P, Cyrus T, Caruthers S, Marsh J, Hughes M, Wickline S.Nanomedicine opportunities in cardiology.Ann N Y Acad Sci. 2006 Oct;1080:451-65.

Li JJ, Wang YA, Guo W, Keay JC, Mishima TD, Johnson MB, Peng X. Large-scale synthesis of nearly monodisperse CdSe/CdS core/shell nanocrystals using air-stable reagents via successive ion layer adsorption and reaction. J Am Chem Soc. 2003 Oct 15;125(41):12567-75.

Li X, Radomski A, Corrigan OI, Tajber L, De Sousa Menezes F, Endter S, Medina C, Radomski MW.Platelet compatibility of PLGA, chitosan and PLGA-chitosan nanoparticles./ Nanomedicine (Lond). 2009 Oct;4(7):735-46.

Luthi AJ, Patel PC, Ko CH, Mutharasan RK, Mirkin CA, Thaxton CS.Nanotechnology for synthetic high-density lipoproteins.Trends Mol Med. 2010 Dec;16(12):553-60. Epub 2010 Nov 17.

Marcus AJ, Broekman MJ, Drosopoulos JH, Islam N, Alyonycheva TN, Safier LB, Hajjar KA, Posnett DN, Schoenborn MA, Schooley KA, Gayle RB, Maliszewski CR. The endothelial cell ecto-ADPase responsible for inhibition of platelet function is CD39.J Clin Invest. 1997 Mar 15;99(6):1351-60.

Marcus AJ, Safier LB, Hajjar KA, Ullman HL, Islam N, Broekman MJ, Eiroa AM. Inhibition of platelet function by an aspirin-insensitive endothelial cell ADPase. Thromboregulation by endothelial cells.J Clin Invest. 1991 Nov;88(5):1690-6.

Marcus AJ, Zucker-Franklin D, Safier LB, Ullman HL. Studies on human platelet granules and membranes. J Clin Invest. 1966 Jan;45(1):14-28.

Massberg S, Schulz C, Gawaz M. Role of platelets in the pathophysiology of acute coronary syndrome.Semin Vasc Med. 2003 May;3(2):147-62.

Matter CM, Stuber M, Nahrendorf M.Imaging of the unstable plaque: how far have we got? Eur Heart J. 2009 Nov;30(21):2566-74. Epub 2009 Oct 15.

Mayer A, Vadon M, Rinner B, Novak A, Wintersteiger R, Fröhlich E. The role of nanoparticle size in hemocompatibility. Toxicology. 2009 Apr 28;258(2-3):139-47. Epub 2009 Jan 22.

McGuinnes C, Duffin R, Brown S, L Mills N, Megson IL, Macnee W, Johnston S, Lu SL, Tran L, Li R, Wang X, Newby DE, Donaldson K. Surface derivatization state of polystyrene latex nanoparticles determines both their potency and their mechanism of causing human platelet aggregation in vitro.Toxicol Sci. 2011 Feb;119(2):359-68. Epub 2010 Dec 1.

Michelson A D, Frelinger A L, Furman M I. Resistance to antiplatelet drugs.2006. European Heart Journal.European Heart Journal, Volume8,G53-G58

Miller VM, Hunter LW, Chu K, Kaul V, Squillace PD, Lieske JC, Jayachandran M. Biologic nanoparticles and platelet reactivity. Nanomedicine (Lond). 2009 Oct;4(7):725-33.

Murray CB, Kagan CR, Bawendi MG. Synthesis and characterization of monodisperse nanocrystals and close-packed nanocrystal assemblies. Ann Rev Materials Sci.2000;30:545-610. 
Nagalla S, Shaw C, Kong X, Kondkar AA, Edelstein LC, Ma L, Chen J, McKnight GS, López JA, Yang L, Jin Y, Bray MS, Leal SM, Dong JF, Bray PF.Platelet microRNA-mRNA coexpression profiles correlate with platelet reactivity.Blood. 2011 May 12;117(19):5189-97. Epub 2011 Mar 17.

Nemmar A, Hoylaerts MF, Hoet PH, Vermylen J, Nemery B. Size effect of intratracheally instilled particles on pulmonary inflammation and vascular thrombosis. Toxicol Appl Pharmacol. 2003 Jan 1;186(1):38-

Nesbitt WS, Giuliano S, Kulkarni S, Dopheide SM, Harper IS, Jackson SP. Intercellular calcium communication regulates platelet aggregation and thrombus growth.J Cell Biol. 2003 Mar 31;160(7):1151-61.

Nikolas Kipshidze.Nanotechnology in Cardiology.BULLETIN OF THE GEORGIAN NATIONAL ACADEMY OF SCIENCES,2009, vol. 3, no. 165-177

Nyman D.Von Willebrand factor dependent platelet aggregation and adsorption of factor VIII related antigen by collagen.Thromb Res. 1980 Jan 1-15;17(1-2):209-14.

Oberdörster G ,Stone V,Donaldson K. Toxicology of nanoparticles: A historical perspective.Nanotoxicology 2007, 1, 2-25.

Patra HK, Banerjee S, Chaudhuri U, Lahiri P, Dasgupta AK. Cell selective response to gold nanoparticles.Nanomedicine. 2007 Jun;3(2):111-9.

Patscheke H. Role of activation in epinephrine-induced aggregation of platelets.Thromb Res. 1980 Jan 1-15;17(1-2):133-42.

Patscheke H.Correlation of activation and aggregation of platelets. Discrimination between anti-activating and anti-aggregating agents.Haemostasis. 1979;8(2):65-81.

Peng X, Manna L, Yang W, Wickham J, Scher E, Kadavanich A, Alivisatos AP. Shape control of CdSe nanocrystals. Nature. 2000 Mar 2;404(6773):59-61.

Peterman EJ, Gittes F, Schmidt CF. Laser-induced heating in optical traps.Biophys J. 2003 Feb;84(2 Pt 1):1308-16.

Petkar KC, Chavhan SS, Agatonovik-Kustrin S, Sawant KK. Nanostructured materials in drug and gene delivery: a review of the state of the art. Crit Rev Ther Drug Carrier Syst. 2011;28(2):101-64.

Plech, A.; Kotaidis, V.; Grésillon, S.; Dahmen, C.; von Plessen, G. Laser-induced heating and melting of gold nanoparticles studied by time-resolved $x$-ray scattering. Published 16 November 2004 (7 pages) 195423

Radomski A, Jurasz P, Alonso-Escolano D, Drews M, Morandi M, Malinski T, Radomski MW . Nanoparticle-induced platelet aggregation and vascular thrombosis. British journal of pharmacology 2005 ;146: 882-893

Ramtoola Z, Lyons P, Keohane K, Kerrigan SW, Kirby BP, Kelly JG. Investigation of the interaction of biodegradable micro- and nanoparticulate drug delivery systems with platelets.J Pharm Pharmacol. 2011 Jan;63(1):26-32. doi: 10.1111/j.20427158.2010.01174.x. Epub 2010 Nov 16.

Rao W, Deng ZS, Liu J. A review of hyperthermia combined with radiotherapy/chemotherapy on malignant tumors.Crit Rev Biomed Eng. 2010;38(1):101-16.

Roberts DE, McNicol A, Bose R. Mechanism of collagen activation in human platelets. J Biol Chem. 2004 May 7;279(19):19421-30. Epub 2004 Feb 23.

Rowley JW, Oler A, Tolley ND, Hunter B, Low EN, Nix DA, Yost CC, Zimmerman GA, Weyrich AS.Genome wide RNA-seq analysis of human and mouse platelet transcriptomes.Blood. 2011 May 19. [Epub ahead of print]

Rückerl R, Phipps RP, Schneider A, Frampton M, Cyrys J, Oberdörster G, Wichmann HE, Peters A.Ultrafine particles and platelet activation in patients with coronary heart disease--results from a prospective panel study.Part Fibre Toxicol. 2007 Jan 22;4:1. 
Shrivastava S, Bera T, Singh SK, Singh G. Ramachandrarao, P.; Dash, D.: Characterization of antiplatelet properties of silver nanoparticles. ACS Nano 2009; 3:1357-1364.

Singha S, Datta H, Dasgupta AK. Size dependent chaperon properties of gold nanoparticles.J Nanosci Nanotechnol. 2010 Feb;10(2):826-32.

Smith AM, Mohs AM, Nie S. Tuning the optical and electronic properties of colloidal nanocrystals by lattice strain. Nat Nanotechnol. 2009 Jan;4(1):56-63. Epub 2008 Dec 7.

Spalding A, Vaitkevicius H, Dill S, MacKenzie S, Schmaier A, Lockette W. Mechanism of epinephrine-induced platelet aggregation. Hypertension. 1998 Feb;31(2):603-7.

Thompson CB.From precursor to product: how do megakaryocytes produce platelets? Prog Clin Biol Res. 1986;215:361-71.

Tschopp TB, Baumgartner HR, Meyer D. Antibody to human factor VIII/von Willebrand factor inhibits collagen-induced platelet aggregation and release.Thromb Res. 1980 Jan 1-15;17(1-2):255-9.

Walkey C, Sykes EA, Chan WC. Application of semiconductor and metal nanostructures in biology and medicine. Hematology Am Soc Hematol Educ Program. 2009:701-7.

Wani M Y, Hashim M A, Nabi F, Malik M A. Nanotoxicity: Dimensional and Morphological Concerns. Advances in Physical Chemistry. Volume 2011 (2011), Article ID 450912, 15 pages. doi:10.1155/2011/450912

Wickline SA, Lanza GM. Nanotechnology for molecular imaging and targeted therapy.Circulation. 2003 Mar 4;107(8):1092-5.

Wickline SA, Neubauer AM, Winter P, Caruthers S, Lanza G. Applications of nanotechnology to atherosclerosis, thrombosis, and vascular biology.Arterioscler Thromb Vasc Biol. 2006 Mar;26(3):435-41. Epub 2005 Dec 22.

Wilson DW, Aung HH, Lame MW, Plummer L, Pinkerton KE, Ham W, Kleeman M, Norris JW, Tablin F.Exposure of mice to concentrated ambient particulate matter results in platelet and systemic cytokine activation.Inhal Toxicol. 2010 Mar;22(4):267-76.

Wilson SR, Sabatine MS, Braunwald E, Sloan S, Murphy SA, Morrow DA. Detection of myocardial injury in patients with unstable angina using a novel nanoparticle cardiac troponin I assay: observations from the PROTECT-TIMI 30 Trial.Am Heart J. 2009 Sep;158(3):386-91. Epub 2009 Jul 15.

Wiwanitkit V, Sereemaspun A, Rojanathanes R. Gold nanoparticles and a microscopic view of platelets: a preliminary observation. Cardiovasc J Afr 2009 ; 20: 141-142.

Wu CC, Teng CM. Comparison of the effects of PAR1 antagonists, PAR4 antagonists, and their combinations on thrombin-induced human platelet activation.Eur J Pharmacol. 2006 Sep 28;546(1-3):142-7.

Wu CC, Wu SY, Liao CY, Teng CM, Wu YC, Kuo SC. The roles and mechanisms of PAR4 and $\mathrm{P} 2 \mathrm{Y} 12 /$ phosphatidylinositol 3-kinase pathway in maintaining thrombininduced platelet aggregation.Br J Pharmacol. 2010 Oct;161(3):643-58.

Yamawaki H, Iwai N. Mechanisms underlying nano-sized air-pollution-mediated progression of atherosclerosis: carbon black causes cytotoxic injury/inflammation and inhibits cell growth in vascular endothelial cells.Circ J. 2006 Jan;70(1):129-40.

Yamawaki H, Iwai N. Mechanisms underlying nano-sized air-pollution-mediated progression of atherosclerosis: carbon black causes cytotoxic injury/inflammation and inhibits cell growth in vascular endothelial cells.Circ J. 2006 Jan;70(1):129-40.

Yu MK, Kim D, Lee IH, So JS, Jeong YY, Jon S.Image-Guided Prostate Cancer Therapy Using Aptamer-Functionalized Thermally Cross-Linked Superparamagnetic Iron Oxide Nanoparticles.Small. 2011 Jun 7. doi: 10.1002/smll.201100472. [Epub ahead of print]. 


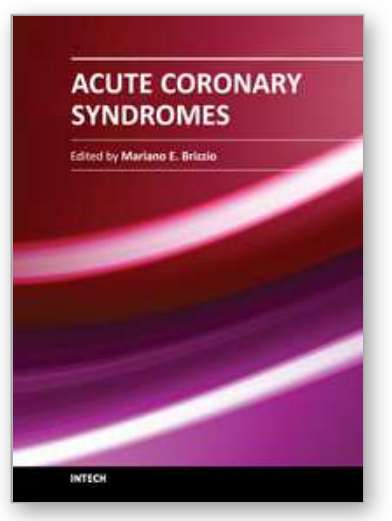

\author{
Acute Coronary Syndromes \\ Edited by Dr. Mariano Brizzio
}

ISBN 978-953-307-827-4

Hard cover, 214 pages

Publisher InTech

Published online 24, February, 2012

Published in print edition February, 2012

This book has been written with the intention of providing an up-to-the minute review of acute coronary syndromes. Atherosclerotic coronary disease is still a leading cause of death within developed countries and not surprisingly, is significantly rising in others. Over the past decade the treatment of these syndromes has changed dramatically. The introduction of novel therapies has impacted the outcomes and surviving rates in such a way that the medical community need to be up to date almost on a "daily bases". It is hoped that this book will provide a timely update on acute coronary syndromes and prove to be an invaluable resource for practitioners seeking new and innovative ways to deliver the best possible care to their patients.

\title{
How to reference
}

In order to correctly reference this scholarly work, feel free to copy and paste the following:

Suryyani Deb and Anjan Kumar Dasgupta (2012). Thrombotic Inception at Nano-Scale, Acute Coronary Syndromes, Dr. Mariano Brizzio (Ed.), ISBN: 978-953-307-827-4, InTech, Available from:

http://www.intechopen.com/books/acute-coronary-syndromes/thrombotic-inception-at-nano-scale-

\section{INTECH}

open science | open minds

\section{InTech Europe}

University Campus STeP Ri

Slavka Krautzeka 83/A

51000 Rijeka, Croatia

Phone: +385 (51) 770447

Fax: +385 (51) 686166

www.intechopen.com

\section{InTech China}

Unit 405, Office Block, Hotel Equatorial Shanghai

No.65, Yan An Road (West), Shanghai, 200040, China

中国上海市延安西路65号上海国际贵都大饭店办公楼 405 单元

Phone: +86-21-62489820

Fax: $+86-21-62489821$ 
(C) 2012 The Author(s). Licensee IntechOpen. This is an open access article distributed under the terms of the Creative Commons Attribution 3.0 License, which permits unrestricted use, distribution, and reproduction in any medium, provided the original work is properly cited. 